\title{
C. Hart Merriam as Anthropologist
}

\section{BY A. L. KROEBER}

C. Hart Merriam was one of the great naturalists of his generation. It is because of his intense drive as a naturalist that he undertook the geographic, ethnological, and linguistic studies of the surviving California Indians of which a part constitutes this book.

For the first half of his adult life, from 1876 to 1910 , Dr. Merriam would have been unhesitatingly classified by all who knew him as a biologist. From I 1910 to 1942 the greater part of his time was spent in the study of historic and living Indians of California, and he was thus de facto an anthropologist. In fact, during at least the latter part of this second period he changed his nominal adherence from the section of biology to the subsection of anthropology in the National Academy of Sciences.

Nevertheless, the same points of view and similar motivations and methods characterized his work in the two halves of his life.

Dr. Merriam was born in northern New York state in 1855 . At the age of seventeen he went with a government exploring expedition to the Yellowstone region and at the age of eighteen published a fifty-page report on the mammals and birds encountered there. Subsequently he studied medicine and practiced actively for several years but never laid aside his preoccupation with living animals. He was only twenty-two when he reviewed the birds of Connecticut and their habits in a publication of the Academy of Arts and Sciences of that state. He was twenty-seven when the first volume of his great Mammals of the Adirondack Region began to appear. A year later he helped found the American Ornithologists' Union and became its secretary and probably most active member. 
At the age of thirty Merriam gave up the practice of medicine to join a section of the government's Department of Agriculture. This section was gradually expanded and became famous as the Biological Survey, of which he was Director.

From the beginning the Biological Survey specialized in mapping the geographical distribution of animals with a view to ascertaining the natural faunal areas or life zones of North America. In I 892, Merriam for the first time formally outlined the life zones of the continent, with increasing emphasis on the mammals.

In 1899 E. H. Harriman, the railroad financier, asked Merriam to organize and direct an Alaskan expedition to accompany him on a vacation during the summer of that year. Merriam also edited the series of volumes that resulted from this many-membered expedition. More important, a personal friendship resulted which led in IgIO to Mrs. Harriman's establishing a trust to be administered by the Smithsonian Institution to provide Merriam with lifetime living and support for research of his own choosing. At the age of fifty-five, accordingly, he resigned his government position, wholly relieved of economic cares, and free to follow his own interests in the work he was henceforth to do.

It was then that he formally switched from subhuman mammals to California Indians. Not that the change was abrupt. In following the intricacies of the life zones of birds, mammals, and plants in California, he had increasingly come across remnants of the aborigines, mostly tucked away in remote spots off from highways. In 1903 he had published his first ethnological paper, one dealing with basket materials, and in the years that followed until IgIo, he had issued eight more such publications, including a book of tales called The Dawn of the World. Nor did he ever abandon biology. As late as 1918 he published his monumental review of the bears of North America. And his very last two papers dealt with Roosevelt as a naturalist and with ocean-dwelling seals. But, as time passed, more and more of Merriam's working time as an explorer and field student was devoted to his Indian friends. He took to living half the year in the wooded country at the rear foot of Mount Tamalpais whose front looks from across the bay down on San Francisco. From there he sallied forth, first on horseback and with wagon, later by automobile, hunting up and interviewing and pumping Indians who were still lingering on in the most out-of-the-way spots of the length and breadth of California.

While the subject matter of Merriam's studies shifted from animals to men in the second half of his career, he brought the same interests, attitudes, and approaches to bear. In each case the distribution of the phenomena dealt with was in the forefront of his attention. His attack merely swung from questions of the precise ranges occupied by species and sub- 
species to the problems of the exact location of aboriginal human languages, tribes, villages, beliefs, and customs. Merriam's definitions of distributions were precise and particularistic, never sketchy. The finest detail of fact seemed worth recording in the interest of accuracy. What he valued was the primary and original data as he secured them in the field: classification and generalization would come later.

As a biologist, the main classification he made was into the life zones already mentioned. Positing of causes was something he scarcely attempted-except for asserting cumulative temperature as the principal determining factor of life zones. Similarly in his ethnology Merriam went as far as to accept and validate the classification of villages into tribes, of tribes into speech families. He did not try to push beyond the family into superstocks or orders, but aimed rather at precision of geographic occurrence of tribes, subtribes, and on down to villages and settlements. This was entirely parallel to his being what used to be called a "splitter" and not a "lumper" in regard to recognition of animal species-as evident in his famous discussion in Science with President Theodore Roosevelt about coyotes and bears. So with his Indians: he cut his data probably finer than did almost any of the anthropologists; but he declined to deal with the principles and general factors that lay beyond the primary organization of the data. As in his biology he wanted to know everything about the mammals and birds of America, but was not concerned with those of other continents, let alone the world as a whole-so in ethnology he restricted himself to the Indians of California and the nearer parts of Nevada and other adjacent states.

In regard to both bodies of material, then, it is evident that Merriam practiced "natural history" rather than "natural science." In some respects his work was comparable to that of a philologist studying a particular language, or a group of related languages, rather than to that of the theoretical linguist. He had the same value for factual accuracy even in minutiae. His work was empirical, basic, and oriented toward attainment of precision and completeness.

Yet in some respects his ethnological work did differ from his biological. He was now working alone, instead of with a corps of associates and assistants as in the days of the Biological Survey. This may have been due to his having become an unhampered free lance; and again it may have had something to do with the restriction of his ethnology to California, whereas his biology ranged over North America. Perhaps the continent was too large for him to cope with singlehanded. Another reason may also have been of some influence. Over most of the United States and Canada the Indians tend to live on reservations that represent only shrunken fragments of their aboriginal habitat. Sometimes they have even been moved 
far from their original centers. In California, however, the Indians, where they survive at all, mostly dwell today where their great-grandfathers did; or if they have retreated, it is usually only a few miles. They have cherefore kept contact and familiarity with their old sod. Their distribution is essentially the "native" or wild one-as in the case of nondomesticated animals. California thus lent itself much more advantageously to precise distribution studies of its Indians than any other part of our country. This fact may have tended to influence Merriam in concentrating his human studies in California.

For decades he spent five to six months each year actually traversing the countryside, interviewing aged Indians and writing down voluminous records of what they were still able to tell him. For while the Indians might live where their ancestors had, they were no longer following the old customs, but were living as best they might as modern Americans-mostly very poverty-stricken Americans at that. The task thus was one in the main of searching their memories. This Merriam did with a patience, tact, and sympathy which elicited coöperation from his informants. To this I can testify from having spoken to many of them with whom Merriam had worked, who always remembered him with affection and approval.

In the course of his many years of this field work, Merriam also read all that had been written on the California Indians and copied and extracted from it voluminously-even to assembling newspaper clippings and personal letters. All this material survives in the vast collection which he left. The core of it, however, consists of his own recordings from the lips of Indians; and what he published during his lifetime is based almost wholly thereon.

Much the same proportion of source holds for the essays which constitute this volume. True, the "synonomies" of tribal and place names are of course from previously published work. Also based on the literature are discussions of the appropriateness or correctness of certain names like Piute, Beñeme, Mono. And again based on records are the Tcholovone vocabulary and the baptismal records from the California missions- - the last doubly valuable because the originals from which Merriam's copies were made have since in part been lost.

Yet the great majority of papers printed here rest flatly and completely on Merriam's own recordings and observations. Perhaps because in his ethnology he worked singlehanded; perhaps for other reasons, such as that an adequate vocabulary is necessarily longer than the description of a species; or that a list of all place names known to a tribe in their territory is more voluminous than a delineation of their geographical range- at any rate Merriam published during his own lifetime only a small fraction of all the Indian material he had gathered. Indeed, though nearly half of his 
professional career was primarily devoted to Indians, he published only twenty-nine papers, articles, and books on them, as against five hundred biological ones. Even during the years when his interest in Indians was most active, I9II-I930, his bibliography shows only twenty titles in ethnology as against sixty in biology. His biological work in the period was evidently still traveling on momentum from the past; whereas the time-consuming preparation of ethnological manuscript was slow in getting under way.

By far the greater mass of Merriam's data on Indians thus has actually never seen the light of publicity. Even the present volume does not too seriously diminish the bulk of what remains unpublished. In fact, what this volume represents is a sort of skimming of the cream, a putting together of those scattered portions of his data which Merriam left most nearly in finished form ready for publication. The much larger but less organized remainder of his original data will no doubt continue to be drawn on for generations as a rich mine of information on the California Indians.

- Merriam stipulated that, whoever it might be that published any of his collected Indian data posthumously, should reproduce him exactly, without alteration, either of his statements or of the form in which he wrote native names.

Both stipulations have been observed in this volume and will be maintained in any future ones.

As regards substance, the proviso obviously is only one of fairness. One does not use another man's laboriously accumulated but unpublished information as grist for one's own mill, as material for one's own views. Scientific as well as moral responsibility are at one in this matter. What Merriam wrote, we, the selectors and editors, have left exactly as he wrote it. Anything added to clarify statements or supply relevance or context has been put into square brackets or otherwise indicated to be clearly distinguishable.

As regards orthography, Merriam held all his life that the "scientific spelling" of anthropologists was a technical mannerism and an unnecessary one. He employed the "common" usage of Webster's Dictionary. It is hard not to have sympathy with this or any view slanted away from pedantic technicalities. It can be said fairly enough that an artificial orthography is in a sense a necessary evil even though it be more accurate -more unambigious. Anthropologists did not come to write native words with the special characters which they have successively employed merely in order to parade arcana of learning before the world. They used them because they felt they had to use them, if they wished to be as clear as possible to other scientists. As a matter of fact, the way they were writing 
Indian words when Merriam entered the field was in a system different from that used when the Bureau of Ethnology was first established in Washington in 1879; and it has in turn been considerably modified since then under the influence of the pure linguists.

Merriam's position corresponded somewhat to that of a hypothetical anthropologist entering the biological field and insisting on never calling a coyote Canis latrans, even in professional journals. If such a hypothetical newcomer to biology brought new information on coyotes, his papers would no doubt be printed, though his insistence would be considered a mannerism. After all, the Latinified binomial nomenclature with its rigid and of ten embarrassing rules of strict priority, its perpetual preservation of typographical errors, its decapitalization of proper names like Washington or Virginia, and other literary barbarisms, has been gradually and in the main reluctantly accepted as a needed instrument by biologists-not as an ornament, flourish, luxury of ostentation, or trademark. And their verdict has been accepted by nonbiological scientists. Similarly as regards the recording of the sounds of words in new or exotic languages: the tendency of general science is to let professional linguists decide how these sounds are best represented in international and scientific writing. So Merriam stood proud and pretty much alone in his adherence to the "common English" ways of writing non-English words; but one can respect the courage and integrity of his aesthetic or temperamental resistance to the majority.

Also, it is to be remembered that Merriam did not set out to do linguistics, did not profess to, and obviously would not have known how. $\mathrm{He}$ remained a natural historian recording the distribution of words as a means to ascertaining the precise distribution of dialects, languages, tribes, families, and their beliefs and customs-as earlier he had recorded the distribution of song sparrows and grizzly bears and yellow pines, of species and subspecies of Canis latrans, in order to delimit life zones. What was at stake was not phonetic or phonemic accuracy as the basis for elucidating grammars-which Merriam never dreamed of doing-but an identification of words. Was the name for house, or for, say, jackrabbit, the same here and in the native village ten miles away, or was it similar, or drastically different? For this purpose, Merriam's nontechnical means definitely sufficed.

As a matter of fact, when simon-pure linguists come to utilize his data for comparative or historical purposes they will almost certainly prefer them in his "everyday English" orthography than if he had tried to write as an imitation linguist. As it is, they will know they have his own original forms. And if they are like the linguists of today, they will themselves transpose his spellings into whatever orthography they will then 
be using, rather than have to guess, from rewritings orthographically "normalized" or "standardized" by, say, Heizer or myself, what in such forms was likely to have been Merriam's and what Heizer's or Kroeber's idea of what Merriam heard. So we, his editors, approve of the rule of unalterability which he laid down, and approve it cheerfully.

While the twenty articles in this book represent not so much what Merriam considered most important in his own work, but what he had happened to have put together most completely, I should like to point out some of his contributions that seem likely to be valued and used most by anthropologists, historians, and those interested in Indians.

There are, for instance, detailed eyewitness accounts of native rituals attended by Merriam, such as the Wintun Big-head, the Pomo Sahte, the Mewuk Mourning Cry, the Autumn Ceremony in Yosemite; or, where the rite had long since been abandoned, like the Kotomut at Tejon, Merriam recorded its description by a surviving native witness and participant. This last account is a genuine treasure recovered, to rank with the accounts of southern California religion by Boscana and Reid. The Sahte record somewhat parallels Barrett's Patwin-Wintun Hesi in both being revivalist versions of parts of ancient aboriginal cult systems. The Bighead is touched on also by Cora Du Bois in her Ghost Dance volume. Mourning Cries were held over much of California; Merriam's is perhaps the fullest description extant.

Of unusual and permanent value are Merriam's photographs of native dwellings and dance houses. This is a uniquely full series, further supplemented by descriptions in other articles, as the one on the Yokiah Pomo.

Very typical are the tribal territory studies, as for the Tuleyome, Mono Paiute, Beñemé, and under "Distribution" in the notes on "Tribes of Wintoon Stock." These are little monographs of intimate landscape utilization and detailed ethnic local history. The pattern for these Merriam had set as early as $19{ }^{\circ}$ with an article in Science on the distribution of tribes in the southern Sierra, and had followed up with detailed studies of the Mewan stock (1907), Yosemite Valley (I917), Pit River tribes (1926), New River Tlohomtahhoi (1930), and Emtimbitch (1930). All of these, like their successors herein, contribute precise information not to be found anywhere else.

From the great mass of vocabulary material which Merriam secured from subtribe after subtribe according to a standardized list, and some of which he also subsequently brought together comparatively, we have extracted for this volume only a slight sample: the native words for "tobacco" and "pipe" in 16r California and Nevada dialects.

From Merriam's copies of the Baptismal Records kept in the Franciscan Missions we reproduce five sets. These give the native name of the settle- 
ment, rancheria, or subtribe to which the converts belonged. They are thus a treasury of local geographical information for those missionized parts of California in which Merriam could not secure the data from the Indians themselves because these had died out before his time or become absorbed in the Mexican population. As these records are dated by years, they also possess direct historical value. They make possible the tracing out of the year-by-year spread of each mission's influence and tributary territory.

Finally, there is a wide array of most diverse themes treated either in short separate topical articles or in sections of tribal ones. Such are native hats; Indians as basket collectors; wild tobacco; native doctors; great Wintun chiefs; acorn cooking; battles and massacres. They illustrate the range of Merriam's interest and activity. 